\title{
Effects of increasing the milk yield of dairy cows on milk composition
}

\author{
P. Huhtanen ${ }^{1,2}$ and M. Rinne \\ Animal Production Research, MTT Agrifood Research Finland \\ FI-31600 Jokioinen, Finland
}

\begin{abstract}
A meta-analysis of published and unpublished data (998 treatment means) comprising of milk production trials in dairy cows fed mainly grass silage-based diets was conducted to examine the effects of increasing milk yield on milk composition. The data was divided into seven subsets investigating the effects of level of concentrate, protein and fat supplementation, carbohydrate composition of the supplement, silage digestibility, silage fermentation quality or replacement of grass silages with legume silages. The relationships between milk yield and milk composition varied depending on dietary management. Both positive and negative relationships between milk yield and concentration of milk components (protein, fat and lactose) were observed. Correlation of milk fat and protein concentration ranged from negative to positive. Most of the relationships can be explained by relative changes in the supply of nutrients absorbed from the digestive tract.
\end{abstract}

KEY WORDS: protein, fat, lactose, feeding, nutrient supply, meta-analysis

\section{INTRODUCTION}

To optimize the economy of milk production the margin over feed cost within the limits of milk quota, animal health and environmental constraints should be maximized. In addition to milk volume, the income depends on milk composition (fat and protein concentration) and quality (bacteria, somatic cells). Milk pricing schemes are different between countries, but an increase in value of milk components - especially protein - at the expense of milk volume has been a general trend in most EU countries.

\footnotetext{
${ }^{1}$ Corresponding author: e-mail: pekka.huhtanen@mtt.fi

${ }^{2}$ Present address: Department of Animal Science, 269 Morrison Hall, Cornell University, NY 14853-4801, USA
} 
Depending on milk pricing schemes the value of the changes in milk yield and milk composition can differ widely, and therefore it would be important to know the effects of increased milk yield on milk composition. It is well established that both genetic and phenotypic correlations between milk yield and concentrations of fat and protein are negative. Genotypic regression coefficients in Finnish Ayrshire for milk protein and fat concentration on milk yield were -0.73 and $-1.23 \mathrm{~g} / \mathrm{kg}$ per $\mathrm{kg}$ increase in milk yield (Juga, 1992). The corresponding phenotypic regressions were -0.36 and -0.56 , respectively. However, when milk yield is increased by improving the diet, the changes in milk composition may not follow the same pattern. For example, positive milk yield responses to higher concentrate supplementation (Gordon, 1984) or increased post-ruminal protein supply (Whitelaw et al., 1986) have been associated with increased protein concentration, whereas fat supplementation has often increased milk yield but decreased protein concentration (Wu and Huber, 1994; Lock and Shingfield, 2004). However, the current information about the changes in milk protein and fat concentration associated with increased milk yield is qualitative rather than quantitative. Both milk yield and milk composition are strongly influenced by stage of lactation, but this subject is not discussed in this paper.

The objective of this study was to estimate the quantitative relationships between changes in milk yield and milk composition associated with increased nutrient supply. The analysis is based on a large data set from production trials in dairy cows fed diets based on grass silage.

\section{MATERIAL AND METHODS}

\section{Description of the data set}

Mean treatment values were collected from dairy cow studies using ad libitum feeding of grass silage based diets ( $\mathrm{n}=998)$. Approximately half of the experiments were conducted in UK, half in Finland and a few in Ireland and Sweden. For the Finnish experiments, also unpublished data was used.

The data was divided into seven subsets based on the amount of concentrate $(n=217)$, protein $(n=363)$ and fat supplementation $(n=29)$, carbohydrate composition of concentrate $(n=114)$, silage digestibility $(n=81)$ and fermentation quality $(n=234)$, and replacement of grass silages with legume silages $(n=48)$. Within each subset only the main factor varied; e.g., in studies investigating the effects of the concentrate level only the amount of concentrate varied but the composition of concentrate and forage were the same within a study. Number of treatment means, dry matter (DM) intake, dietary concentrations of crude protein (CP) and neutral detergent fibre (NDF), and milk production parameters for the whole data are shown in Table 1. 
Table 1. Feed intake and milk production

\begin{tabular}{lccccc}
\hline Item & $\mathrm{n}$ & Mean & $\begin{array}{c}\text { Standard } \\
\text { deviation }\end{array}$ & Minimum & Maximum \\
\hline $\begin{array}{l}\text { DM intake, kg/d } \\
\text { In diet DM, g/kg }\end{array}$ & 998 & 17.9 & 2.82 & 9.9 & 25.2 \\
$\quad$ CP & 998 & 165 & 21.5 & 101 & 252 \\
$\quad$ NDF & 998 & 407 & 50.0 & 195 & 571 \\
Milk production, kg/d & & & & & \\
$\quad$ milk & 998 & 25.4 & 5.05 & 13.0 & 45.8 \\
ECM & 998 & 26.1 & 5.14 & 12.8 & 42.1 \\
Milk composition, g/kg & & & & & \\
$\quad$ protein & 998 & 32.1 & 1.70 & 25.9 & 37.8 \\
$\quad$ fat & 998 & 42.8 & 3.96 & 31.9 & 55.0 \\
$\quad$ lactose & 985 & 48.2 & 1.66 & 43.7 & 52.3 \\
Component yield, g/d & & & & & \\
$\quad$ protein & 998 & 814 & 171 & 359 & 1449 \\
$\quad$ fat & 998 & 1081 & 217 & 479 & 1671 \\
$\quad$ lactose & 985 & 1228 & 250 & 607 & 2172 \\
\hline
\end{tabular}

\section{Statistical analysis}

Mixed model regression procedure of SAS (Littell et al., 1996) was used to estimate linear and quadratic effects of independent response variables (e.g., amount of concentrate) on milk production parameters.

The model was:

$$
\mathrm{Y}=\mathrm{B}_{0}+\mathrm{B}_{1} \mathrm{X}_{\mathrm{ij}}+\mathrm{B}_{2} \mathrm{X}_{\mathrm{ij}}^{2}+\mathrm{b}_{0}+\mathrm{b}_{1} \mathrm{X}_{\mathrm{ij}}+\mathrm{e}_{\mathrm{ij}}
$$

where $\mathrm{B}_{0}+\mathrm{B}_{1} \mathrm{X}_{\mathrm{ij}}+\mathrm{B}_{2} \mathrm{X}_{\mathrm{ij}}$ are the fixed effects, $\mathrm{b}_{0}$ and $\mathrm{b}_{1}$ are the random study effects (intercept and slope), $i=1 \ldots n$ studies and $j=1 \ldots n_{i}$ values.

In quadratic models only the linear effect of independent variable was a random factor, because the models using quadratic effect as a random factor did not generally converge. Mixed model analysis removes the variation in experimental protocols, animal types and laboratory assays which contribute to study effects in these regressions, i.e. the relationships between $\mathrm{Y}$ and $\mathrm{X}$ variables within a study are investigated. Rationale and further details of using mixed model analysis to integrate quantitative findings from multiple studies are described by St-Pierre (2001).

The following parameters were used in the sub-datasets to estimate the responses in milk production parameters to changes in diet composition: 
1. Amount of concentrate (CDMI): concentrate DM intake

2. Protein supplementation (PSuppl): CP concentration in the diet

3. Fat supplementation (FAT): fatty acid concentration of the diet (fatty acids were estimated using empirical relationships between ether extract and fatty acids; unpublished)

4. Carbohydrate composition of concentrate $(\mathrm{CHO})$ : NDF concentration in concentrate

5. Silage digestibility ( $\mathrm{D}$-value): silage $\mathrm{D}$-value

6. Silage fermentation quality (SFQ): total acid concentration in the diet

7. Replacement of grass with legume (Legume): proportion of legume in forage DM.

Adjusted Y values (adjusted observations) for milk production parameters were calculated as $\mathrm{Y}$ adjusted $=\mathrm{Y}$ predicted + residual. The $\mathrm{Y}$ predicted is simply value on the regression line (adjusted for random study effects). Residuals were generated by SAS OUTP option in the model.

The relationships between milk yield and milk composition were estimated by a simple regression model of the form:

$$
\mathrm{Y}=\mathrm{B}_{0}+\mathrm{B}_{1} \mathrm{X}_{\mathrm{ij}}+\mathrm{e}_{\mathrm{ij}}
$$

where $\mathrm{B}_{0}+\mathrm{B}_{1} \mathrm{X}_{\mathrm{ij}}$ are the fixed effects.

When the relationships appeared to be curvilinear also a quadratic term $\left(\mathrm{B}_{2} \mathrm{X}_{\mathrm{ij}}^{2}\right)$ was included in the model. It should be noted that adjusted values of milk yield and milk composition were used in this analyses.

A set point analysis was made for the relationships between milk yield and milk fat by Excel Solver. The data was fitted to linear regressions with a set point by minimizing the residual mean squared error between observed predicted values. The corresponding proportion of concentrate was estimated from the relationship from the quadratic regression equation between concentrate intake and milk yield.

\section{RESULTS}

The data showed large variation both in diet composition in terms of $\mathrm{CP}$ and NDF concentrations and in milk production (Table 1). Within sub-datasets the variation was smaller but still substantial.

\section{Amount of concentrate}

Milk yield, milk protein and lactose concentrations and yield of milk components increased quadratically with increased level of concentrate supplementation. Milk 
fat concentration varied quadratically with the amount of concentrate reaching a maximum value at concentrate DM intake of $4.3 \mathrm{~kg} / \mathrm{d}$. Responses to increased concentrate feeding were relatively consistent within studies as indicated by small residual mean square error (RMSE) of adjusted milk yield $(0.37 \mathrm{~kg} / \mathrm{d})$.

Higher milk yield resulting from increased concentrate feeding was positively associated with milk protein and lactose concentrations but negatively associated with milk fat concentration (Table 2). The effect of increased milk yield on fat concentration was curvilinear with relatively small changes below adjusted milk yield of $28 \mathrm{~kg} / \mathrm{d}$ (Figure 1). Set point analysis described changes in

Table 2. Effects of increased milk yield in response to increased concentrate feeding on milk composition and yield of milk components

\begin{tabular}{lccccccc}
\hline Item & $\mathrm{B}_{0}$ & s.e. $^{1}$ & $\mathrm{~B}_{1}$ & s.e & $\mathrm{P}$ & Adj. $\mathrm{R}^{2}$ & RMSE $^{2}$ \\
\hline Concentration, g/kg & & & & & & & \\
$\quad$ protein & 23.2 & 0.31 & 0.36 & 0.012 & $<0.001$ & 0.807 & 0.38 \\
$\quad$ fat & 52.9 & 0.94 & -0.38 & 0.036 & $<0.001$ & 0.339 & 1.17 \\
$\quad$ lactose & 46.3 & 0.15 & 0.07 & 0.006 & $<0.001$ & 0.424 & 0.19 \\
Protein/fat & 0.358 & 0.0182 & 0.015 & 0.0007 & $<0.001$ & 0.690 & 0.023 \\
& & & & & & & \\
Yield, g/d & & & & & & & \\
$\quad$ protein & -217 & 7.7 & 40.7 & 0.298 & $<0.001$ & 0.989 & 9.6 \\
$\quad$ fat & 239 & 30.5 & 33.2 & 1.177 & $<0.001$ & 0.787 & 37.9 \\
$\quad$ lactose & -58 & 6.6 & 50.5 & 0.254 & $<0.001$ & 0.995 & 8.2 \\
\hline
\end{tabular}

${ }^{1}$ standard error

${ }^{2} \mathrm{RMSE}$ - residual mean squared error

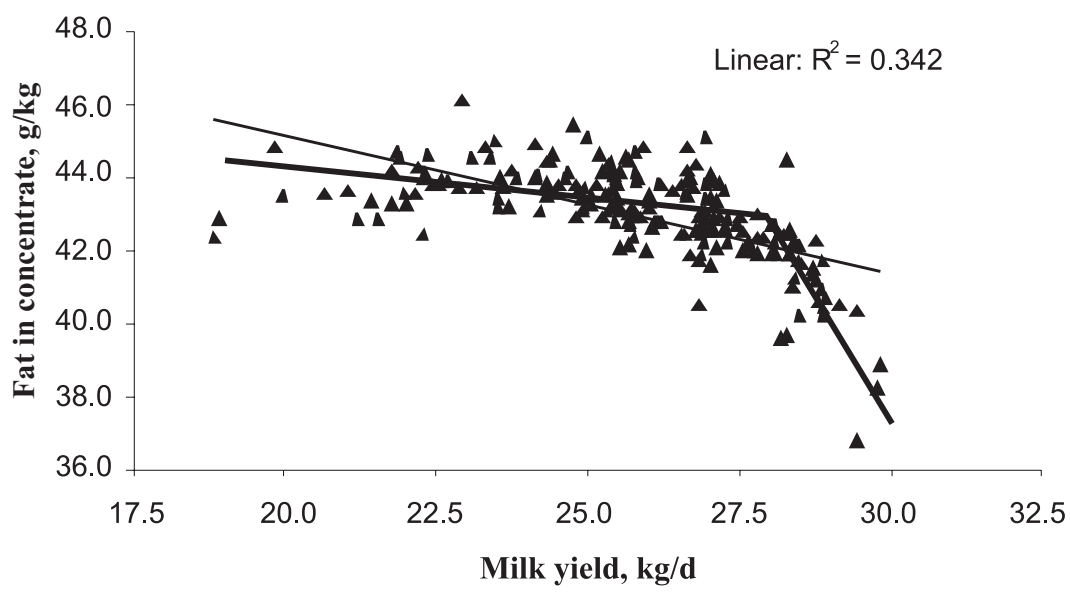

Figure 1. The effects of milk yield associated with increased amount of concentrate feeding on milk fat concentration 
milk fat concentration much better than the linear trend $\left(\mathrm{R}^{2}=0.60 \mathrm{vs} 0.34\right)$. The set point was at adjusted milk yield of $28 \mathrm{~kg} / \mathrm{d}$, which coincides with a concentrate proportion of 0.57 in diet DM. Protein and fat concentrations were negatively correlated $(\mathrm{r}=-0.44 ; \mathrm{P}<0.001)$.

The yield of milk components increased as milk yield increased with concentrate feeding (Table 2). The effects were very consistent for protein and lactose yields, but fat yield responses associated with increased milk yield were more variable. The slope of regression represents concentrations of protein, fat and lactose in incremental milk yield. For example, additional milk contained 40.7 and 33.2 $\mathrm{g} / \mathrm{kg}$ of protein and fat, respectively.

\section{Protein supplementation}

Milk yield increased quadratically in studies investigating the effects of protein supplementation. The RMSE of adjusted milk yield was $0.47 \mathrm{~kg} / \mathrm{d}$. Milk yield was positively related to milk protein concentration and negatively to fat and lactose concentrations in these studies (Table 3). However, protein

Table 3. Effects of increased milk yield in response to protein supplementation on milk composition and yield of milk components

\begin{tabular}{lccccccc}
\hline Item & $\mathrm{B}_{0}$ & s.e. $^{1}$ & $\mathrm{~B}_{1}$ & s.e. & $\mathrm{P}$ & Adj. $^{2}$ & RMSE $^{2}$ \\
\hline Concentration, g/kg & & & & & & & \\
$\quad$ protein & 25.1 & 0.32 & 0.27 & 0.012 & $<0.001$ & 0.584 & 0.31 \\
$\quad$ fat & 58.0 & 0.90 & -0.57 & 0.034 & $<0.001$ & 0.437 & 0.87 \\
$\quad$ lactose & 50.5 & 0.20 & -0.09 & 0.007 & $<0.001$ & 0.307 & 0.19 \\
$\quad$ milk urea, mg/L & -942 & 38.2 & 47.0 & 1.46 & $<0.001$ & 0.797 & 28.6 \\
$\quad$ corrected protein & 28.7 & 0.41 & 0.11 & 0.016 & $<0.001$ & 0.159 & 0.31 \\
Protein/fat & 0.316 & 0.0170 & 0.017 & 0.0006 & $<0.001$ & 0.646 & 0.017 \\
Yield, g/d & & & & & & & \\
$\quad$ protein & -167 & 8.4 & 39.1 & 0.318 & $<0.001$ & 0.977 & 8.2 \\
$\quad$ fat & 317 & 22.5 & 30.8 & 0.851 & $<0.001$ & 0.783 & 21.9 \\
$\quad$ lactose & 40 & 6.0 & 45.6 & 0.226 & $<0.001$ & 0.991 & 5.8 \\
\hline
\end{tabular}

${ }^{1}$ standard error

${ }^{2}$ RMSE - residual mean squared error

supplementation increased significantly milk urea concentration with the mean response being $47 \mathrm{mg}$ urea/ $\mathrm{kg}$ additional milk. Consequently, the effect of increased milk yield on urea-corrected protein concentration was less than half of that observed for uncorrected protein concentration. Increased milk yield in response to supplementary protein feeding was associated with higher protein to fat ratio in milk. Additional milk contained 39.1, 30.8 and $45.6 \mathrm{~g} / \mathrm{kg}$ of protein, fat and lactose, respectively. Milk protein or urea-corrected protein and fat concentration were negatively correlated $(\mathrm{P}<0.001)$. 


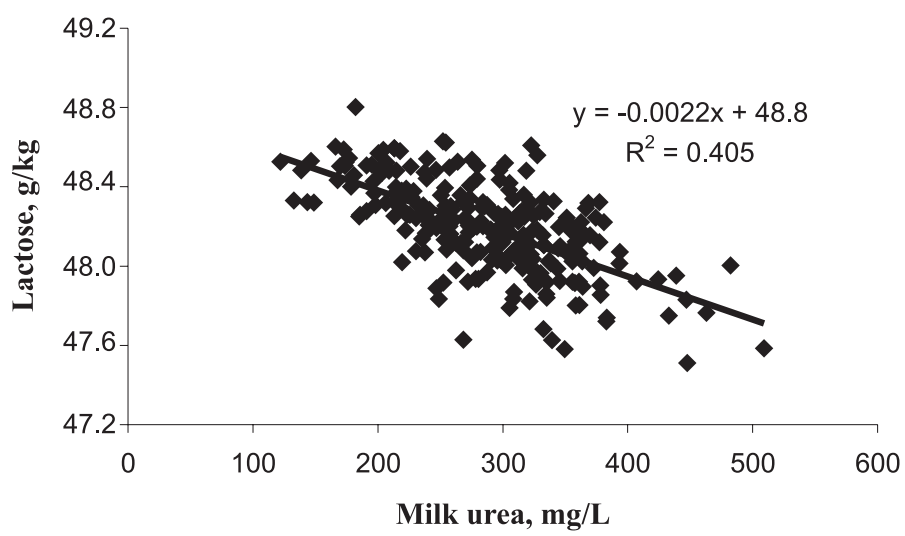

Figure 2. Relationship between milk urea and lactose concentrations in protein supplementation studies ( $\mathrm{n}=265$ diets)

Milk urea concentration was negatively related to lactose concentration (Figure 2). Although the variation in adjusted lactose concentration was small (range from 47.4 to $48.7 \mathrm{~g} / \mathrm{kg}$ ), the effect of urea concentration on lactose concentration was strongly significant $(\mathrm{P}<0.001)$.

\section{Fat supplementation}

Milk yield increased quadratically with increasing fatty acid concentration of diet reaching maximum at $48 \mathrm{~g} / \mathrm{kg} \mathrm{DM}$ in fat supplementation studies. Milk protein concentration decreased $(\mathrm{P}<0.001)$ with increasing milk yield, but fat and lactose concentrations were not associated with milk yield (Table 4 ). The yields of milk components increased with milk yield, but the slope of regression was only 16.1 for milk protein yield.

Table 4. Effects of increased milk yield in response to fat supplementation on milk composition and yield of milk components

\begin{tabular}{lccccccc}
\hline Item & $\mathrm{B}_{0}$ & s.e. $^{1}$ & $\mathrm{~B}_{1}$ & s.e. & $\mathrm{P}$ & Adj. $^{2}$ & RMSE $^{2}$ \\
\hline $\begin{array}{l}\text { Concentration, g/kg } \\
\quad\end{array}$ & 47.0 & 2.43 & -0.59 & 0.092 & $<0.001$ & 0.585 & 0.44 \\
$\quad$ protein & 43.0 & 8.41 & -0.16 & 0.319 & 0.63 & -0.028 & 1.52 \\
$\quad$ fat & 45.3 & 2.75 & 0.06 & 0.104 & 0.54 & -0.023 & 0.50 \\
$\quad$ lactose & 1.129 & 0.1802 & -0.012 & 0.0068 & 0.09 & 0.068 & 0.033 \\
$\quad$ protein/fat & & & & & & & \\
Yield, g/d & 407 & 59.8 & 16.1 & 2.268 & $<0.001$ & 0.637 & 10.8 \\
$\quad$ protein & 72 & 233.6 & 35.5 & 8.869 & $<0.001$ & 0.349 & 42.3 \\
$\quad$ fat & -69 & 76.2 & 49.6 & 2.892 & $<0.001$ & 0.913 & 13.8 \\
$\quad$ lactose & & & & & & & \\
\hline
\end{tabular}

${ }^{1}$ standard error

${ }^{2} \mathrm{RMSE}$ - residual mean squared error 


\section{Carbohydrate composition of the energy supplement}

Carbohydrate composition of the concentrate had only minor effects on milk yield as indicated by the narrow range $(24.9-26.8 \mathrm{~kg} / \mathrm{d})$ and the small coefficient of variation $(1.24 \%)$ in adjusted milk yield, i.e. within a study the differences between diets were very small.

Milk protein concentration decreased $(\mathrm{P}<0.001)$ and lactose concentration increased $(\mathrm{P}<0.01)$ with increased milk yield (Table 5), whereas milk fat

Table 5. Effects of changes in milk yield associated with concentrate carbohydrate composition on milk composition and yield of milk components'

\begin{tabular}{lccccccc}
\hline Item & $\mathrm{B}_{0}$ & s.e. $^{1}$ & $\mathrm{~B}_{1}$ & s.e. & $\mathrm{P}$ & Adj. $^{2}$ & RMSE $^{2}$ \\
\hline Concentration, g/kg & & & & & & & \\
$\quad$ protein & 49.0 & 3.37 & -0.66 & 0.131 & $<0.001$ & 0.175 & 0.45 \\
$\quad$ fat & 37.2 & 3.63 & 0.16 & 0.141 & 0.27 & 0.002 & 0.48 \\
$\quad$ lactose & 43.2 & 1.47 & 0.16 & 0.057 & 0.006 & 0.062 & 0.18 \\
Protein/fat & 1.263 & 0.0965 & -0.019 & 0.0038 & $<0.001$ & 0.177 & 0.013 \\
& & & & & & & \\
Yield, g/d & & & & & & & \\
$\quad$ protein & 310 & 84.2 & 19.9 & 3.279 & $<0.001$ & 0.241 & 11.1 \\
$\quad$ fat & -134 & 181.7 & 46.5 & 7.076 & $<0.001$ & 0.272 & 24.0 \\
$\quad$ lactose & -27 & 40.2 & 48.3 & 1.565 & $<0.001$ & 0.903 & 4.8 \\
\hline
\end{tabular}

${ }^{1}$ standard error

${ }^{2}$ RMSE - residual mean squared error

concentration was not significantly influenced by milk yield in concentrate carbohydrate composition studies. Protein to fat ratio in milk was negatively related to milk yield. The correlation between milk fat and protein concentrations was small and insignificant. Milk component yields increased with milk yield, but the slope for protein yield was markedly lower than the mean protein concentration in these studies ( 19.9 vs $32.1 \mathrm{~g} / \mathrm{kg}$ ), i.e. extra milk produced in response to changing concentrate carbohydrate composition had a low protein concentration.

\section{Silage digestibility}

Milk yield increased linearly in studies investigating the effects of silage digestibility on milk production. Milk yield was positively correlated with all milk components, although numerically the increase in lactose was small (Table 6). Due to greater increase in milk protein compared with fat concentration, the protein to fat ratio in milk increased with increased yield. When silage digestibility was improved by harvesting at earlier stage of grass growth additional milk had both high protein and fat concentrations as indicated by high slopes of protein and fat 
yield on milk yield (39.4 and $50.4 \mathrm{~g} / \mathrm{d}$, respectively). Protein and fat concentrations were not significantly correlated $(\mathrm{r}=0.14 ; \mathrm{P}=0.11)$.

Table 6. The effects of increased milk yield in response to improved silage digestibility on milk composition and yield of milk components

\begin{tabular}{lcllllll}
\hline Item & $\mathrm{B}_{0}$ & s.e. $^{1}$ & $\mathrm{~B}_{1}$ & s.e. & $\mathrm{P}$ & Adj. $^{2}$ & RMSE $^{2}$ \\
\hline $\begin{array}{l}\text { Concentration, g/kg } \\
\quad\end{array}$ & & & & & & & \\
$\quad$ protein & 22.4 & 1.59 & 0.41 & 0.065 & $<0.001$ & 0.323 & 0.79 \\
$\quad$ fat & 37.8 & 2.30 & 0.19 & 0.094 & 0.047 & 0.037 & 1.15 \\
$\quad$ lactose & 46.6 & 0.51 & 0.05 & 0.021 & 0.013 & 0.064 & 0.26 \\
Protein/fat & 0.609 & 0.0534 & 0.006 & 0.0022 & 0.005 & 0.084 & 0.027 \\
Yield, g/d & & & & & & & \\
$\quad$ protein & -173 & 30.2 & 39.4 & 1.23 & $<0.001$ & 0.927 & 15.1 \\
$\quad$ fat & -192 & 44.9 & 50.4 & 1.84 & $<0.001$ & 0.904 & 22.5 \\
$\quad$ lactose & 13 & 15.3 & 47.4 & 0.63 & $<0.001$ & 0.986 & 7.7 \\
\hline
\end{tabular}

${ }^{1}$ standard error

${ }^{2}$ RMSE - residual mean squared error

\section{Silage fermentation quality}

Milk and especially fat and protein yields decreased linearly with increasing total acid concentration in silage. In-silo fermentation was manipulated by using different additive treatments (e.g., untreated, inoculants, enzymes, acids). Milk fat and protein concentrations were positively $(\mathrm{P}<0.001)$ related to milk yield in studies investigating the effects of silage fermentation characteristics (Table 7).

Table 7. The effects of milk yield on milk composition and yield of milk components in studies investigating the effects of silage fermentation quality

\begin{tabular}{lcllllll}
\hline Item & $\mathrm{B}_{0}$ & s.e. $^{1}$ & $\mathrm{~B}_{1}$ & s.e. & $\mathrm{P}$ & Adj. $^{2}$ & RMSE $^{2}$ \\
\hline $\begin{array}{l}\text { Concentration, g/kg } \\
\quad\end{array}$ & & & & & & & \\
$\quad$ protein & 21.8 & 1.42 & 0.43 & 0.059 & $<0.001$ & 0.185 & 0.61 \\
$\quad$ fat & 22.4 & 3.10 & 0.89 & 0.129 & $<0.001$ & 0.167 & 1.34 \\
$\quad$ lactose & 51.6 & 0.76 & -0.10 & 0.032 & 0.003 & 0.035 & 0.33 \\
Protein/fat & 0.858 & 0.0394 & -0.005 & 0.0016 & 0.002 & 0.037 & 0.017 \\
Yield, g/d & & & & & & & \\
$\quad$ protein & -180 & 33.8 & 39.5 & 1.41 & $<0.001$ & 0.771 & 14.6 \\
$\quad$ fat & -485 & 79.1 & 63.6 & 3.30 & $<0.001$ & 0.615 & 34.2 \\
$\quad$ lactose & 78 & 19.1 & 46.0 & 0.80 & $<0.001$ & 0.935 & 8.3 \\
\hline
\end{tabular}

${ }^{1}$ standard error

${ }^{2}$ RMSE - residual mean squared error 
In silage fermentation studies milk yield and lactose concentration were negatively correlated. Protein to fat ratio in milk was negatively $(\mathrm{P}<0.01)$ related to milk yield. Incremental milk yield had high protein, and especially fat concentration. In silage fermentation studies milk fat and protein concentrations were strongly and positively correlated $(\mathrm{r}=0.72 ; \mathrm{P}<0.001)$.

\section{Replacement of grass with legume silages}

Diets containing white clover silages were excluded from the analysis, because of very low NDF concentrations and generally different milk yield and composition responses compared with red clover, the most commonly used forage legume in Northern Europe. Milk protein concentration decreased with increased milk yield in studies examining the replacement of grass silages with legume silages (Table 8). Also milk fat concentration was negatively associated

Table 8. The effects milk yield on milk composition and yield of milk components in studies investigating the effects of replacement of grass silage with legume silages

\begin{tabular}{lccccccc}
\hline Item & $\mathrm{B}_{0}$ & s.e. ${ }^{1}$ & $\mathrm{~B}_{\perp}$ & s.e. & $\mathrm{P}$ & Adj. $^{2}$ & RMSE $^{2}$ \\
\hline $\begin{array}{l}\text { Concentration, g/kg } \\
\quad\end{array}$ & & & & & & & \\
$\quad$ protein & 37.0 & 1.65 & -0.20 & 0.059 & 0.001 & 0.186 & 0.39 \\
$\quad$ fat & 48.0 & 5.38 & -0.18 & 0.193 & 0.35 & -0.002 & 1.27 \\
$\quad$ lactose & 44.6 & 1.14 & 0.13 & 0.041 & 0.003 & 0.159 & 0.27 \\
Protein/fat & 0.774 & 0.0903 & -0.0016 & 0.00324 & 0.62 & -0.016 & 0.021 \\
Yield, g/d & & & & & & & \\
$\quad$ protein & 173 & 45.8 & 25.1 & 1.64 & $<0.001$ & 0.831 & 10.8 \\
$\quad$ fat & 244 & 146.6 & 34.1 & 5.26 & $<0.001$ & 0.466 & 34.5 \\
$\quad$ lactose & -101 & 48.1 & 51.8 & 1.73 & $<0.001$ & 0.950 & 11.3 \\
\hline
\end{tabular}

${ }^{1}$ standard error

${ }^{2}$ RMSE - residual mean squared error

with milk yield, but the effect was not significant. Lactose concentration increased with milk yield $(\mathrm{P}<0.01)$. Due to reduced concentrations of protein and fat in milk, additional milk had relatively low concentrations of protein and fat.

\section{DISCUSSION}

The objective of the present study was to examine quantitative relationships between milk yield and milk composition, when the most common dietary means to increase milk yield were investigated. A mixed model regression analysis was 
used to exclude study effects from the total variation, i.e. relationships between adjusted values within a study were investigated.

\section{Milk protein concentration}

Protein is the most valuable milk component and therefore there has been a continuous interest to increase milk protein concentration by nutritional means. The present analysis demonstrated that in most cases when the nutrition of cows is improved (CDMI, PSuppl, D-value and SFQ studies), milk yield and protein concentrations were positively correlated. The positive effects of the level of concentrate supplementation on both milk yield and protein concentration are well established, but in many protein supplementation studies the effects have failed to reach statistical significance. The effect of concentrate level on protein concentration is quadratic, and at high levels of supplementation milk protein concentration can decline (e.g., Ferris et al., 1999). Significant positive effects of both improved silage digestibility (Rinne, 2000) and restricted in-silo fermentation (Huhtanen et al., 2003) on milk protein concentration have been reported from meta-analyses. In both cases these responses can be attributed to increased silage DM intake, and consequently increased energy supply to rumen microbes. Restricting in-silo fermentation will also increase microbial protein supply (Harrison et al., 2003), because water solubles carbohydrates provide more energy for the growth of rumen microbes than silage fermentation products.

A general feature of the four nutritional means is that both the supply of metabolizable energy and protein (amino acids absorbed from small intestine; AAT) calculated according to MTT (2006) increased. However, there were substantial differences in the relative changes in ME and AAT supply (Table 9).

Table 9. The effects of response variables on metabolizable energy (ME) and protein (AAT) intake and the ratio of protein to lactose (PY/LY) in additional milk yield

\begin{tabular}{|c|c|c|c|c|c|}
\hline \multirow[b]{2}{*}{ Subject } & \multirow[b]{2}{*}{ Variable } & \multicolumn{2}{|c|}{ Intake response } & \multirow[b]{2}{*}{$\begin{array}{c}\mathrm{AAT} / \mathrm{ME} \\
\mathrm{g} / \mathrm{MJ}\end{array}$} & \multirow[b]{2}{*}{$\mathrm{PY} / \mathrm{LY}$} \\
\hline & & $\begin{array}{c}\mathrm{ME} \\
\mathrm{MJ} / \mathrm{d}\end{array}$ & $\begin{array}{c}\mathrm{AAT} \\
\mathrm{g} / \mathrm{d}\end{array}$ & & \\
\hline $\mathrm{CDMI}^{1}$ & CDMI, $\mathrm{g} / \mathrm{kg}$ diet DM & 7.51 & 72.2 & 9.61 & 0.80 \\
\hline PSuppl $^{2}$ & $\mathrm{~g} \mathrm{CP}^{3} / \mathrm{kg} \operatorname{diet} \mathrm{DM}$ & 0.222 & 5.64 & 25.37 & 0.85 \\
\hline D-value & $\mathrm{g} \mathrm{DOM}^{4} / \mathrm{kg}$ silage DM & 0.325 & 2.56 & 7.87 & 0.81 \\
\hline $\mathrm{SFQ}^{5}$ & $\mathrm{~g} \mathrm{TA}^{6} / \mathrm{kg} \operatorname{diet} \mathrm{DM}$ & -0.333 & -2.55 & 7.68 & 0.77 \\
\hline
\end{tabular}

${ }^{1}$ concentrate dry matter intake; ${ }^{2}$ protein supplementation; ${ }^{3}$ crude protein; ${ }^{4}$ digestible organic matter;

${ }^{5}$ silage fermentation quality; ${ }^{6}$ total acids

Despite a wide range in the additional substrate supply the regression coefficients of protein yield on lactose yield were similar for the four means of dietary manipulation. This suggests that it is very difficult to increase milk protein yield 
more than lactose yield by dietary treatments. With post-ruminal casein infusion, which probably results in the highest amino acid to energy ratio in incremental nutrient supply (approximately $50 \mathrm{~g}$ AAT per MJ ME), the protein to fat ratio in additional milk yield was slightly above 1.0 (Huhtanen, 1998). Marginal lactose yield response to increased ME supply was markedly higher in PSuppl studies (7.1 g per MJ ME) compared with CDMI (4.9), D-value (4.6) and SFQ (4.0) studies, respectively. This indicates that part of the increased supply of AAT from supplementary protein was used for gluconeogenesis and therefore was not completely available for milk protein synthesis. Indeed, abomasal infusion of casein has shown to increase glucose flux in dairy cows (Clark et al., 1977).

In PSuppl studies a large proportion of increased milk protein concentration resulted from increased milk urea concentration. This conclusion is based on an assumption that milk analysers were calibrated for crude protein, which was the case at least in the Finnish studies. In some studies milk protein was analysed by Kjeldahl method. It should also be noted that increases in milk yield in PSuppl studies were associated with large increases in milk urea concentration, which is a strong indicator of reduced efficiency of $\mathrm{N}$ utilization (Nousiainen et al., 2004).

Fat supplementation often increased milk yield but decreases milk protein concentration (e.g., Wu and Huber, 1994; Lock and Shingfield, 2004), in agreement with the present study. Fat supplements have often been used to replace starchy supplements, which reduces the concentration of metabolizable protein in the diet. However, increasing amino acid supply by post-ruminal casein infusion did not alleviate the adverse effect of fat supplementation on milk protein concentration (Cant et al., 1993).

In the present meta-analysis milk yield and protein concentration were negatively correlated in studies investigating the substitution of cereal grains by fibrous by-products. In single studies published in the literature the effects have been variable. The adverse effect on milk protein concentration sometimes reported for fibrous by-products may be related to the inclusion of fat supplements in order to compensate for the lower energy concentration of fibrous by-products compared with cereal grains. In the present data, the concentrate fat and NDF concentrations were positively correlated $(\mathrm{P}<0.001)$ suggesting that increased diet fat concentration may, at least partly, explain the lower milk protein concentration with increasing concentrate NDF concentration. When low-fat high NDF byproducts such as sugar-beet pulp were compared with barley, no differences in milk protein concentration were observed (Castle et al., 1981; Huhtanen, 1987). It should also be noted that the effects of concentrate carbohydrate composition on milk production were marginal and therefore the overall effect on milk protein concentration is not very large despite strongly negative regression coefficient.

The negative relationship between milk yield and protein concentration, when grass silage was partly or completely replaced with legume, mainly red-clover 
silages, is difficult to explain. Replacing grass silage with legumes increased milk yield quadratically reaching the maximum when legumes comprised proportionally 0.72 of the total silage DM. Protein flow to the small intestine has increased when red-clover has replaced grass silage in the diet (Dewhurst et al., 2003; Vanhatalo et al., 2006) but increased protein flow has been utilized inefficiently in milk protein synthesis. Protein to lactose ratio in incremental milk yield was 0.47 in legume studies, which is much lower than those shown in Table 9 but slightly higher than in FAT (0.34) and CHO studies (0.31). This suggests that the nutrient supply from diets based on red-clover silages favoured lactose rather than protein yield. The low ratio between protein and lactose yield increases is similar to that observed in post-ruminal glucose infusion studies (Huhtanen, 1998). However, rumen fermentation pattern and protein flow measurements do not suggest greater relative increases in glucogenic nutrients compared with aminogenic nutrients in legume studies (Dewhurst et al., 2003; Vanhatalo et al., 2006).

\section{Milk fat concentration}

In most cases increases in milk yield were associated with reduced milk fat concentration. When the amount of concentrates was increased, milk fat concentration was not markedly influenced before adjusted milk yield reached 28 $\mathrm{kg} / \mathrm{d}$ corresponding proportionally 0.57 concentrate DM of total DM. A similar set point pattern was observed for milk fat yield; additional $\mathrm{kg}$ of milk increased fat yield by $40.9 \mathrm{~g}$ when the proportion of concentrate was below 0.57 , but above it milk fat yield decreased by $60 \mathrm{~g}$ per $\mathrm{kg}$ increase in milk yield. Set point analysis explained the variation between milk and fat yield better than linear regression $\left(\mathrm{R}^{2} 0.90\right.$ vs 0.79$)$. The study of Gordon (1984) is a good example that in cows fed grass silage milk fat concentration is resistant to changes in the level of concentrate supplementation. The small responses in milk fat concentration to increased concentrate feeding are consistent with small effects of dietary starch concentration and proportion of concentrate on rumen VFA pattern in cows fed grass silage-based diets (Sveinbjörnsson et al., 2006). Weiss et al. (2003) concluded that a feature of diets based on grass silage is that the profile of the three major ruminal VFA are resistant to changes in response to addition of starchy concentrates. At high levels of concentrate inclusion, the decreases in both milk fat concentration and yield may be related to changes in rumen biohydrogenation and increased flow of trans-10 isomers of C18:1 to the small intestine (Griinari et al., 1998).

The negative relationship between milk yield and milk fat concentration in studies investigating the effects of increased protein supplementation is more likely to be a dilution effect rather than a consequence of changes in the supply of milk fat precursors to the mammary gland. A strong positive relationship between adjusted milk and fat yield supports this suggestion. Protein supplementation 
of grass silage-based diets increases both silage DM intake (Oldham, 1984; Huhtanen, 1998) and diet digestibility (Oldham, 1984) providing precursors for increased milk fat synthesis.

Increased milk yield in response to improved silage digestibility was associated with a small increase in milk fat concentration in spite of reduced NDF concentration in the diet. This can be related to rumen fermentation pattern high in butyrate in cows fed highly digestible silages (Rinne et al., 2002). Intraruminal butyrate infusions have increased milk fat concentration (Miettinen and Huhtanen, 1996).

Increased milk yield resulting from restricted silage fermentation was associated with increased fat concentration as indicated by a high $(63.6 \mathrm{~g} / \mathrm{kg})$ fat concentration in the additional milk yield. These responses are likely to be explained by increased silage DM intake (Huhtanen et al., 2003) with reduced total acid concentration and associated changes in rumen fermentation pattern. Residual sugars in restrictively fermented silages will favour increased proportions of acetate and butyrate in rumen VFA (van Vuuren et al., 1995; Harrison et al., 2003), whereas lactic acid is fermented to propionate (van Vuuren et al., 1995; Sveinbjörnsson et al., 2006). The strong positive correlation between fat and protein concentrations in silage fermentation studies is likely to be explained by relative changes in milk fat precursors; the supply of both fat (acetate and butyrate) and protein precursors (microbial protein) increase, whereas the supply of main lactose precursor (propionate) decreases as the extent of in-silo fermentation is restricted.

\section{Milk lactose concentration}

Lactose is the main regulator of osmotic pressure in milk and lactose synthesis determines the milk volume. Generally the effects of diet composition on lactose concentration have been small and seldom statistically significant. Fish meal supplementation (Broderick, 1992) and increased butyrate supply manipulated by intraruminal infusions (Miettinen and Huhtanen, 1996) are few examples of studies, in which significant dietary effects on lactose concentration have been reported.

Although in single studies dietary effects on lactose concentration are seldom significant, the present meta-analysis showed strongly significant relationships between response variables (e.g., concentrate DM intake, dietary CP concentration) and lactose concentration, and between milk yield and lactose concentration. Regression coefficients between milk yield and lactose concentration varied from approximately $0.15 \mathrm{~g} / \mathrm{kg}$ per $\mathrm{kg}$ milk in CDMI, CHO and Legume studies to approximately -0.10 in PSuppl and SFQ studies. At least in CDMI, PSuppl and SFQ studies there is enough data ( $>200$ treatment means) allowing to hypothesize possible mechanisms. 
In CDMI studies glucose supply increases with increased concentrate supplementation mainly due to increased DM intake and increased duodenal starch flow, but possibly also because of changes in rumen fermentation pattern, at least at high proportions of concentrate. Entry rate of glucose is closely related to digestible energy intake (Elliot, 1980) and increases approximately $115 \mathrm{~g}$ per $\mathrm{kg}$ increase in DM intake. In the present data milk yield increased $1.3 \mathrm{~kg}$ per $\mathrm{kg}$ increase in total DM intake, when the amount of concentrate supplementation was increased. This corresponds to about $90 \mathrm{~g}$ increase in glucose requirement (Danfær, 1994), i.e. the supply of glucose increased more than the requirement with high concentrate diets.

The negative relationship between milk yield and lactose concentration in protein supplementation studies was associated with increased milk urea concentration. It is possible that urea increased the osmotic pressure in milk and therefore less lactose was needed to excrete additional milk produced with improved amino acid supply. A similar negative relationship between urea and lactose concentrations was observed in practical milk samples (Nousiainen J., personal communication). However, although the negative relationship between milk yield and lactose concentration was highly significant, lactose concentration in additional milk was only marginally lower than the mean lactose concentration (45.6 vs 48.0) in protein supplementation studies.

Milk lactose concentration increased significantly with total acid concentration in the diet. Because increased TA concentration was associated with reduced milk yield, lactose concentration decreased with milk yield when silage fermentation was restricted. As discussed above, molar proportion of propionate in ruminal VFA is directly related to the concentration of lactic acid in silage. High lactate silages have sometimes increased plasma glucose concentration compared with restrictively fermented silages (Heikkilä et al., 1998; Shingfield et al., 2002) suggesting that glucose supply may limit milk yield in cows fed restrictively fermented silages.

\section{CONCLUSIONS}

The present analysis demonstrated that when milk yield is manipulated by dietary management, the relationships between milk yield and milk composition are in most cases different from genotypic and phenotypic correlations. Milk protein concentration increases with milk yield, when the nutrition of cows is improved by feeding more concentrates and supplementary protein or when the digestibility or fermentation quality of silage is improved. Milk fat concentration is reduced with increased concentrate and protein supplementation, but the effects on concentrate feeding on fat concentration are small below the set point in concentrate proportion ( 0.57 of total $\mathrm{DM})$. The relationships between milk fat 
and protein concentration were variable depending on how diet composition was changed ranging from negative (e.g., CDMI) and non-significant (e.g., silage D-value) to strongly positive (silage fermentation quality). Statistically significant positive relationships between milk yield and lactose concentration were observed. Generally the observed relationships can be explained by relative changes in the supply of glucogenic, lipogenic and aminogenic nutrients absorbed from the digestive tract.

\section{REFERENCES}

Broderick G.A., 1992. Relative value of fish meal versus solvent soybean meal for lactating dairy cows fed alfalfa silage as sole forage. J. Dairy Sci. 75, 174-183

Cant J.P., DePeters E.J., Baldwin R.L., 1993. Mammary amino acid utilisation in dairy cows fed fat and its relationship to milk protein depression. J. Dairy Sci. 76, 762-774

Castle M.E., Gill M.S., Watson J.N., 1981. Silage and milk production: a comparison between barley and dried sugar-beet pulp as silage supplements. Grass Forage Sci. 36, 319-324

Clark J.H., Spires H.R., Derrig R.G., Bennink M.R., 1977. Milk production, nitrogen utilization and glucose synthesis in cows infused postruminally with sodium caseinate and glucose. J. Nutr. 107, 631-644

Danfær A., 1994. Nutrient metabolism and utilization in the liver. Livest. Prod. Sci. 39, 115-127

Dewhurst R.J., Evans R.T., Scollan N.D., Moorby J.M., Merry R.J., Wilkins R.J., 2003. Comparisons of grass and legume silages for milk production. 2. In vivo and in sacco evaluations of rumen function. J. Dairy Sci. 86, 2612-2621

Elliot J.M., 1980. Propionate metabolism and vitamin B12. In: Y. Ruckebush, P. Thivend (Editors). Digestive Physiology and Metabolism in Ruminants. MTP Press, Lancaster (England), pp. 485

Ferris C.P., Gordon F.J., Patterson D.C., Kilpatrick D.J., Mayne C.S., McCoy M.A., 1999. The response of dairy cows of high genetic merit to increasing proportion of concentrate in the diet with a high and medium feed value silage. J. Agr. Sci. 136, 319-329

Gordon F.J., 1984. The effect of level of concentrate supplementation given with grass silage during the winter on the total lactation performance of autumn-calving dairy cows. J. Agr. Sci. 102, 163-179

Griinari J.M., Dwyer D.A., McGuire M.A., Bauman D.E., Palmquist D.L., Nurmela K.V.V., 1998. Trans-octadecenoic acids and milk fat depression in lactating dairy cows. J. Dairy Sci. 81, 12511261

Harrison J., Huhtanen P., Collins M., 2003. Perennial grasses. In: D.R. Buxton, R.E. Muck, J.H. Harrison (Editors). Silage Science and Technology. American Society of Agronomy, pp. 665747

Heikkilä T., Toivonen V., Huhtanen P., 1998. Effects of and interactions between the extent of silage fermentation and protein supplementation in lactating dairy cows. Agr. Food Sci. Finland 7, 329-343

Huhtanen P., 1987. The effect of dietary inclusion of barley, unmolassed sugar beet pulp and molasses on milk production, digestibility and digesta passage in dairy cows given silage based diet. J. Agr. Sci. Finland 59, 101-120

Huhtanen P., 1998. Supply of nutrients and productive responses in dairy cows given diets based on restrictively fermented silage. Agr. Food Sci. Finland 7, 219-250 
Huhtanen P., Nousiainen J.I., Khalili H., Jaakkola S., Heikkilä T., 2003. Relationships between silage fermentation characteristics and milk production parameters: analyses of literature data. Livest. Prod. Sci. 81, 57-73

Juga J., 1992. Estimation of variances and covariances of milk traits by REMP with individual animal model. Acta Agr. Scand., Sect. A, Anim. Sci. 42, 198-204

Littel R.C., Milliken G.A., Stroup W.W., Wolfinger R.D., 1996. SAS® System for Mixed Models. SAS Inst. Inc., Cary, NC

Lock A.L., Shingfield K.J., 2004. Optimising milk composition. In: E. Kebreab, J. Mills, D.E. Beever (Editors). Dairying-Using Science to Meet Consumers' Needs. British Society of Animal Science, Publication No. 29, Nottingham University Press, Loughborough (UK), pp. 107-188

Miettinen H., Huhtanen P., 1996. The effects of ruminal propionate to butyrate ratio on milk production and blood metabolites in dairy cows fed a grass silage based diet. J. Dairy Sci. 79, 851-861

MTT, 2006. Feed Tables and Feeding Recommendations (in Finnish). Jokioinen: MTT Agrifood Research Finland. Updated 14 February 2006. Cited 16 June 2006. Available on the Internet: http://www.agronet.fi/rehutaulukot/. URN:NBN:fi-fe20041449

Nousiainen J., Shingfield K., Huhtanen P., 2004. Evaluation of milk urea nitrogen as a diagnostic of protein feeding. J. Dairy Sci. 87, 386-398

Oldham J.D., 1984. Protein energy relationships in dairy cows. J. Dairy Sci. 67, 1090-1114

Rinne M., 2000. Influence of the timing of the harvest of primary grass growth on herbage quality and subsequent digestion and performance in the ruminant animal. Academic Dissertation, University of Helsinki, Department of Animal Science, Publications 54, pp. $42+5$ encl., Available on the Internet: http://ethesis.helsinki.fi/julkaisut/maa/kotie/vk/rinne/

Rinne M., Huhtanen P., Jaakkola S., 2002. Digestive processes of dairy cows fed silages harvested at four stages of maturity. J. Anim. Sci. 80, 1986-1998

Shingfield K., Jaakkola S., Huhtanen P., 2002. Effect of forage conservation method, concentrate level and propylene glycol on diet digestibility, rumen fermentation, blood metabolite concentrations and nutrient utilization of dairy cows. Anim. Feed Sci. Tech. 97, 1-21

St-Pierre N.R., 2001. Integrating quantitative findings from multiple studies using mixed model methodology. J. Dairy Sci. 84, 741-755

Sveinbjörnsson J., Huhtanen P., Udén P., 2006. The Nordic dairy cow model, Karoline - Development of volatile fatty acid sub-model. In: E. Kebreab, J. Dijkstra, A. Bannink, W.J.J. Gerrits, J. France (Editors). Nutrient Digestion and Utilization in Farm Animals: Modelling Approaches. CAB International, pp. 1-14

Vanhatalo A., Kuoppala K., Ahvenjärvi S., Rinne M., 2006. The effect of red clover silage on the nutrient supply to dairy cows (in Finnish). Maataloustieteen Päivät 2006 (electronic publication). Suomen Maataloustieteellisen Seuran julkaisuja No 21. A. Hopponen (Editor). Available on the Internet: http://www.smts.fi/pos06/1105.pdf. ISBN 951-9041-49-4

van Vuuren A.M., Huhtanen P., Dulphy J.-P., 1995. Improving the feeding and health value of ensiled forages. In: M. Journet, E. Grenet, M.-H. Farce, M. Theriez, C. Demarquilly (Editors). Recent Developments in the Nutrition of Herbivores. INRA, Paris, pp. 297-307

Weiss W.P., Chamberlain D.G., Hunt C.W., 2003. Feeding silages. In: D.R. Buxton, R.E. Muck J.H. Harrison (Editors). Silage Science and Technology. American Society of Agronomy, pp. 665-747

Whitelaw F.G., Milne J.S., Ørskov E.R., Smith J.S., 1986. The nitrogen and energy metabolism of lactating cows given abomasal infusion of casein. Brit. J. Nutr. 55, 537-556

Wu Z., Huber J.T., 1994. Relationship between dietary-fat supplementation and milk proteinconcentration in lactating cows - a review. Livest. Prod. Sci. 39, 141-155 